\title{
The Unboxing the Legal Background for Women Involvement in Indonesia's Peacekeeping Operation Mission: Challenges and Opportunities
}

\author{
E Dewi ${ }^{1}$, P A N I P Satya ${ }^{2}$, T R Arsanti ${ }^{3}$ \\ ${ }^{1,2}$ Parahyangan Centre for International Studies ${ }^{3}$ Resilience Development Initiative \\ ${ }^{1}$ elisabeth.dewi@unpar.ac.id, ${ }^{2} \underline{\text { naraindra.prima@unpar.ac.id, }}{ }^{3}$ teresa.arsanti@rdi.or.id
}

\begin{abstract}
Despite of the acknowledgement of Resolution 1325 that has highlighted the low level of women participation in Peacekeeping Operation (PKO), which resulted in ineffectiveness of PKO, Indonesia contributes the lowest number of women peacekeepers compared to the other Southeast Asian Countries. On the other hand, Indonesia has actually recognized the importance of women's participation and made progress as Indonesia has increased its female peacekeepers in the UN mission. Several challenges hamper women's involvement in PKO such as how women need to get husband's written consent to let his wife takes part in PKO. Furthermore, the need for women's involvement in peacekeeping process is rising to a new level. Women's position in the conflicting area is very vulnerable and often affected as a main victim from the conflict. Realizing both the effort and challenges in Indonesia, it is important to understand how women are being involved in the PKO. This paper contributes to filling the gap in the limited study of gender and peacekeeping operations (PKO) from Indonesia's perspective. The purpose of this paper is to provide an evaluation/assessment based on gender perspective to the debate of practice or role of women in PKO supported by the legal instrument studies. This article is trying to examine both of the domestic legal instrument and the UN legal instrument in creating the environment for the involvement of women in Indonesia's PKO mission. This could be done by analyzing to what extent the gender mainstreaming has been considered and conducted in Indonesian PKO. More specifically, through the qualitative approach, the paper will examine how the PKO in Indonesia should involve women's role as the peacekeeping actors and how far the PKO regulation has accommodated the involvement of women in PKO through the feminist legal method. The paper concludes that through the gender perspective, the involvement of women in PKO has not accommodated optimally. Within the commitment, Indonesia has recognized the importance of women's role in the PKO. However, this commitment has not been translated yet through the constitution of Indonesia. Finally, the roles of women in the PKO mission are still limited to their 'given' role in society such as clerical staff and desk job compared to the man who actively involved in frontline mission.
\end{abstract}

Keywords: Women Peacekeeper, Peacekeeping Operation, Gender Mainstreaming, United Nations, Indonesia 


\section{INTRODUCTION}

Indonesia is one of the most active countries in the United Nation's (UN) PeaceKeeping Operation (PKO) throughout the world. According to UN's peacekeeping website, Indonesia is sending nearly 2,700 combined military and police officers to nine PKO as of 30 June 2019 [1]. The Indonesian Ministry of Foreign Affairs claimed that Indonesia topped at $8^{\text {th }}$ position from 124 countries that sent their personnel to the UNPKO [2]. This fact has made Indonesia as one of the main contributors for UNPKO in Asia and the world. Furthermore, Indonesia even solidified her contribution by announcing the Minister of Foreign Affairs Regulation No. 05/2015 on Roadmap Vision 4,000 Peacekeepers 2015-2019.

The increasing of Indonesia personnel in UNPKO is coming hand-in-hand with the larger contribution of the women in the missions. Indonesia has sent 106 female peacekeepers in eight UN Peacekeeping Missions throughout the world as per May 2019 [2]. Most of the female personnel came from the Tentara Nasional Indonesia (Indonesian National Army). The Indonesian National Army Head of General Staff Joni Supriyanto said that Indonesia commits to increase the percentage of women peacekeepers from $4 \%$ in 2019 to $7 \%$ in the future [3].

The larger Indonesian commitment to involve women in UNPKO is not merely resulted from the gender mainstreaming trends in $\mathrm{UN}$, but also from the practical needs in the operation itself. Nowadays, the victims of the conflict mostly came from the women and children, while the perpetrators are men. The Indonesian women PKO personnel had actively participated as a mediator in this situation. For example, the Indonesian women PKO role in the United Nations Interim Force in Lebanon (UNIFIL) included the interaction with women and children in a predominantly Shiite-dominated society in South Lebanon in which women prohibited from communicating with men [4]. Women also proved to be a focal factor in the CIMIC (Civil Military Cooperation) operation such as in the Indobatt (Indonesian Mechanical Battalion) in which have a larger interaction with the most vulnerable group in the conflictaffected society namely the women and children.

The UNPKO in contemporary time is facing more challenges from the gender-based violence (GBV) and conflict-related sexual violence (CRSV). Both of this case is arguably needs more involvement of women as an early-peacebuilders to handle the negative effect of the violence. As an example, the experience of Lieutenant Colonel Ratih Pusporini, one of the women PKO personnel in Kongo, proved to be the example for the significance of it. In 2008, while served for UNPKO mission in Congo, Pusporini went into one village to collect the data about sexual abuse. Her team managed to get the information because they consisted of women, while the previous team did not gain the information because all of the members were men. The victims, who mostly are women, were too scared to talk with men about their experience about the sexual abuse [2].

Ratih Pusporini is the first women personnel who served in Indonesian UNPKO mission. One year later, the number of Indonesian women UNPKO personnel increased from one to 5 persons in 2009, 19 persons in 2014, and 24 persons in 2015 [5]. The role which conducted by the women personnel are ranging from staff officers, military staff, battalion staff, and military staff officers. Both of the women and men personnel have the same duties, responsibilities, and obligations regarding the instructions from the chief officer. The women personnel are also instructing to protect the civilians, guarding the observation post, securing the area, guarding the contingent rotation, and investigating every violence case that might have been conducted by UNIFIL military personnel in the mission area [5].

Despite of the optimism about the greater role of Indonesian women in UNPKO, there are still problems to be resolved. First, even though Indonesia had a significant number of 
UNPKO personnel, the percentage of women in the overall personnel is relatively low comparing to another country that had lesser personnel. For example, the percentage of Indonesian women personnel from 2009 to 2014 is static at the 2\% meanwhile Philippines can deploy between $4 \%$ to $12 \%$ women in their total personnel, despite the higher GDP and democracy index in Indonesia [6]. This condition is resulted from the fact that women had a limited access to the military academy in which opened for them from only 2013. Thus, women's role in the military is limited because of their lack of experience that resulted from the fact that they cannot fill all roles in the military, especially in combat positions. This is also combining with their lack of proper language ability especially in English.

Another burden that troubled the chance of women to pass the selection for Indonesian UNPKO mission is they have to get permission from their spouse in order to join the unit [6]. This policy logic comes from the traditional perspective that women have the "motherhood" roles to take care of their family, especially the children. When the women leave their family, another person cannot replace this role. Even when they already deployed in the field, this perspective only allows women to the military offices works. The women personnel involvement in the real battle or conflict is very rare. In the end, they stationed as clerical staff, deputy assistant, and staff officers [5].

The facts above show that one of the main burdens for the greater roles of the women personnel comes from the policy and rules from the government itself. Both of them are still lingered with patriarchy culture and positioning women as a subordinate in the power relations inside the peacekeeping mission. Furthermore, this research is trying to examine the involvement of women in the peacekeeping mission. This research comes with one main question: how far the PKO regulation has accommodated the involvement of women in PKO missions abroad. The main argument of this research is the Indonesian regulation towards women personnel in peacekeeping operation are still lagging behind the UN regulation which ideally functioning as main reference for it. This condition is a result from the patriarchy perspective that still embedded in the cultural point of view in the society. In addition, this cultural point of view is the main foundation of the regulation that still positioned women as a subordinate in the society.

\section{RESEARCH METHOD}

This paper utilizes the qualitative methodology with the approach to explore and understand the significance of the social and humanitarian issue. In the process of qualitative methodology, there will be questions and procedure that occur, and then followed up by the data collection, inductive analysis, just by then the meaning from the data could be interpreted and written [7]. This paper focuses on the analysis of secondary data through the literature review. This paper describes the law regarding peacebuilding in Indonesia in depth through the content analysis by applying the gender perspective on it. The content of the regulation will then be analyzed through the framework of feminist legal methods. Therefore, it applied to describe to what extent gender aspects have been considered and applied in Indonesian peacebuilding regulation.

In the past thirty years, law has had been undeniable impacted by the feminism. Law itself is a human artifact that constructed by individuals acting within the social context. The law that especially enacted in America, constructed almost typically by the male. Therefore, feminists believe that law is mainly man-gendered [8].

Based on the so-called man-gendered law, feminists have developed extensive approach about what the "doing" of law should recite and the status to provide for the 
followed legal claims. These approaches are in the form of critiques and proposals for the legal reformation. Pointing out this approach, feminists realizes that they do need the feminist methods in case of better challenging the existing structures of power within the law, avoiding to recreate the illegitimate power structures. The feminist methods, developed by Barlett, distinguish itself from traditional legal methods with its substantive-methods to criticizing the existing power structures, value-rule flexibility, and the capability to identify missing points of view [9]. Aside from feminist legal methods' distinction to the ordinary legal methods, feminist "do law" just as what the other lawyers do. This "do law" covers the facts of a legal issue examination, the essential features identification, deciding the foundation legal principles, and those principal implementations. Further, feminists introduce feminist legal methods that have been utilized not only to analyze the look for reform of existing legal approaches, but also to maintain its distinctiveness as it could be regarded as a significant challenge to traditional and dominant legal doctrine [10].

Feminist legal method laying its focus on women; however, this method could see other excluded groups. Barlett concluded that feminist legal methods, especially its "woman question", that it converts the woman question into the question of the excluded [11]. It based on the argument with the consideration of Barlett's perspective to understand other excluded groups, Nussbaum's "Politics of Humanity" to see other as a person, and Leslie Green thought of toleration.

According to Barlett, there are three methods to reflect the statuses of women in law namely are: (a) asking the "woman question" as a way to challenge the existing elements in legal doctrine that perhaps leave out the excluded groups.; (b) feminist practical reasoning as a reasoning of pragmatic responses to existing problems instead of static choices between opposing perspectives; (c) consciousness-raising, looking for insights and improve perspectives through collaborative or interactive engagements that draw upon personal experience and narrative [9].

"Asking the woman question" has three main features. It identifies bias against women that may implicit in regulation that appears neutral and objective. Besides, it reveals how law leaves the experiences and values of women out, and suggests the application of legal rules that do not enshrine women's subordination [11]. This method asks about the implication of gender within the social practice or rule. By asking these questions, this specific method examines how the law has failed to take into account women's experiences and values. Such questions should asked, whether or not women have been left out of consideration, how this negligence should be improved, and what difference would make it to do so [9]. In addition, such question that assumes the women impact on law shall asked as it mentioned by Janet Ainsworth, "What would the law be like if women had been considered by the drafters and interpreters of the law?"

Once this method adopted, it acts as integral to legal analysis as deciding the precedential value of a case, declaring the facts, or applying law to facts. This method acts as the method and procedure that separated from the substance of the law. However, it is inevitable to say that all legal methods shape substance. Therefore, instead of debating whether the methods have substantive consequences, it is important to ensure that the method and substance is having "proper" relationship.[9]

\section{RESULTS AND DISCUSSION}

The discussion of this paper starts with a question, "Where are the Indonesian women?" According to BPS 2018 data, women accounted for 49.76 per cent of the total population, but 
only 56.13 have access to jobs, compared to 89.16 per cent of the male population. Female participation is even lower in the governance sector, with only 17.32 per cent of women occupying positions as national parliamentarians [12]. Yet, female participation in public roles is increasing compared to a decade ago, except that, arguably, in defense and the security sectors (including institutions that manage and provide security for the state and its people, i.e. the police and military forces) they remain a male domain. Data on women in the Indonesian women police that consist of between 5 to 8.3 per cent in each division making it difficult to assess the rate of women participation as well as their welfare in terms of equal pay for equal employment, career track and retention [13]. Nira Yuval-Davis emphasizes that women fulfil vital roles in the defense and security sector, but often do not contribute on an equal basis to that of the men [14]. This is because the sexual division of labor in defense and security is often more rigid and more focused on physical power than in the civil sector. Indonesian history records that there have been women warriors since ancient times, and there are women currently serving in conflict, but men still outnumber women as armed forces personnel, and women are historically rendered suitable only as cooks, nurses and as aides of war, i.e. those positioned as civilians, rather than as fighters. There is a low advocacy supporting women to obtain equal work in the defense and security sectors compared to support for women entering politics and economics. This likely reflects society's uneasiness about accepting women into the security environment, most often because women are stereotyped to fill domestic roles tied to housekeeping and childrearing.

The discussion of this paper followed by a question "where are Indonesian women in PKO?" Given official UN recognition of the importance of women in peacekeeping operations, this paper is essential to trace how Indonesian government support women citizen entering the security and defense forces, and deploying them in national contingents for UN peacekeeping missions. It is interesting to investigate the underlying cause of this relatively small number of women in Indonesian peacekeeping missions, and to examine the country's efforts of increase the women's participation rate. At the opening of Indonesia Peacekeeping Training Centre in 2012, Indonesia has been publicly requested by the UN Secretary General Ban Ki Moon to increase its women peacekeepers. The UN Secretary General especially highlighted the importance of women peacekeepers in supporting women survivors of sexual violence, who find it difficult to report to male UN peacekeepers and officers due to fear, shame and trauma [14].

Finally, the paper ended by a question, "where are Indonesian female PKO in the national regulations?" The paper looks at four related regulations at different levels and year.

Figure 1. Indonesian National Regulations

\begin{tabular}{|c|c|c|c|}
\hline $\begin{array}{c}\text { Presidential Regulation } \\
\text { No. } 85 \text { of } 2011\end{array}$ & $\begin{array}{l}\text { RI Minister of Foreign } \\
\text { Affairs Regulation } \\
\text { No. } 5 \text { of } 2015\end{array}$ & $\begin{array}{l}\text { Presidential Regulation } \\
\text { No. } 86 \text { of } 2015\end{array}$ & $\begin{array}{l}\text { RI Minister of Foreign } \\
\text { Affairs Regulation } \\
\text { No. } 1 \text { of } 2017\end{array}$ \\
\hline $\begin{array}{l}\text { - Establishment of the } \\
\text { Peace Maintenance } \\
\text { Mission (TKMPP) Team, } \\
\text { chaired by the Minister of } \\
\text { Foreign Affairs and } \\
\text { consisting of Ministers / } \\
\text { Leaders of Institutions } \\
\text { related to the United } \\
\text { Nations MPP. }\end{array}$ & $\begin{array}{l}\text { - Vision Road Map 4,000 } \\
\text { 2015-2019 Peace Care } \\
\text { Personnel as a strategic } \\
\text { reference in realizing } \\
\text { these 4,000 } \\
\text { peacekeepers Vision. }\end{array}$ & $\begin{array}{l}\text { - Delivery of Peace } \\
\text { Maintenance Missions. } \\
\text { This Presidential } \\
\text { Regulation became the } \\
\text { legal basis for the } \\
\text { delivery of Indonesian } \\
\text { personnel and troops to } \\
\text { various MPPs, both held } \\
\text { by the United Nations } \\
\text { and regional } \\
\text { organizations. }\end{array}$ & $\begin{array}{l}\text { - Revision of RI Minister of } \\
\text { Foreign Affairs Regulation } \\
\text { No. } 5 \text { of } 2015 \text { about } \\
\text { vision road map 4,000 } \\
\text { peacekeeper in 2015- } \\
2019\end{array}$ \\
\hline
\end{tabular}


Source: Adapted from various websites [15], [16], [17], [18]

From the list above, this paper is asking "the women questions" for the regulations above. It is finding that the first three regulations do not mention "women" at all. In another word, women were out of discussion and not became the center of discussion. Only the last regulation mentions the word "women" 10 times and points out women for several issues [18], a) Government of Indonesia committed to send 40 women police as part of Indonesian contribution in 2016 during the Leaders' Summit on Peacekeeping in New York 2015; b) Government of Indonesia admitted that the number of women peacekeeper still less than other neighbor countries. Therefore, it is very important to increase the number of women peacekeepers with their own challenges. It has to be provided with proper incentive based on strategic interests and obligations, including International Covenant on Civil and Political Rights (ICCPR), Convention on the Elimination of Discrimination Against Women (CEDAW) and UNSCR 1325 on Women, Peace and Security; c) Government of Indonesia sent 12 personnel for United Nations Supervision Mission in Suriah (UNSMIS) based on UN's requested that consisted of 11 men and only 1 woman; d) As part of Roadmap Vision 4,000 peacekeepers, Government Indonesian conducted socialization to increase the participation of women personal peacekeepers in 2016; e) In 2016, Government of Indonesia involved the International Association of Women Police to increase the number of women peacekeepers; f) In 2017, Government of Indonesia increased the number and quality of Indonesian women personnel with skill set at UNPKO and UNHQ; g) Using the contribution and participation of women peacekeepers to support the nomination of Indonesia as non-permanent member of UNSC, during the year of 2017.

Although the last regulation already mentioned "women" related to several issues as above, but this paper is questioning whether that regulation is already written using a feminism point of view or not? Has the regulation written from the perspective of what women can do? Has the specific arguments of the regulation is collectively termed feminism?

This paper further argues that in the regulation discusses, feminism has not become focus on how gender shapes consciousness, skills and institutions as well as the distribution of power and privileges among Indonesian women PKO. The regulation already acknowledges women as a human in front of the law but not success yet to change the invisibility of the female experience and to work towards the goal of ending women's unequal social, economic and political position in Indonesia. The regulation does not touch the discussion that female's definition of security is inevitably different from that of men. Furthermore, the regulation does not touch the reality that women see security as multi-level and multidimensional. The regulation is still considering that all women have a similar point of view and it shows how women seen as a homogenous group. The regulation fails to recognize that just as there are different types of people in the world, then so the perspectives of women differ. The problem is that female involvement in protecting the nation has been restrained by the traditional reluctance of the family, and national and international society, so limiting the opportunities for women to make meaningful contributions. As there is a broad spectrum of the different types of feminism, it is valuable to examine the different strands of how women try to define and create security for all, both for women and men.

\section{CONCLUSIONS}

Implementing feminist legal method, this paper is questioning the Government of Indonesia commitment to increasing the number and role of Indonesian female peacekeepers, 
in order to support the achievement of UN targets for holding minimum female personnel of $15 \%$ as military observers and staff officers and $20 \%$ as police personnel in the United Nations MPP in 2020. It proven that Government of Indonesia needs to recognize that contribution to increasing the effectiveness of implementing the mandate has to highlight efforts of winning the hearts and minds of the local community, especially women. It is not only women as homogenous community but also more importantly women with their heterogenic backgrounds, experiences, skills and challenges.

Along with the dynamics of the challenges and mandate of the United Nations MPP, Indonesia has to recognize women personnel also have their unique roles in helping the MPP UN's efforts to prevent Sexual Exploitation and Abuse (SEA). In this connection, Government of Indonesia need to conduct a comprehensive training series that emphasizes the importance of Prevention SEA to Indonesian peacekeepers from the gender equality point of view and variety of feminism approaches.

Lastly, to improve aspects of safety and security of personnel, Government of Indonesia needs to continue to improve the quality of capability of the unit equally for men and women, in line with the commitment to strengthen the United Nations MPP contained in the Action for Peacekeeping initiative launched by the UN Secretary General in 2018.

\section{REFERENCES}

[1] L. A. Alexandra and Á. N. Á. Civil, "Rethinking Energy Security in Asia: A Non-Traditional View of Human Security," vol. 2, pp. 21-37, 2012.

[2] Kementerian Luar Negeri Republik Indonesia, "Peran Krusial Penjaga Perdamaian Perempuan Sebagai Agen Perdamaian Toleransi Dan Kemakmuran," Portal Kementerian Luar Negeri Republik Indonesia, 2019. [Online]. Available: https://kemlu.go.id/portal/id/read/343/berita/perankrusial-penjaga-perdamaian-perempuan-sebagai-agen-perdamaian-toleransidan-kemakmuran. [Accessed: 15-Dec-2019].

[3] L. Satria, "Indonesia Tambah Personel Perempuan Pasukan Perdamaian Dunia | Republika Online," Republika Online, 2019. [Online]. Available: https://internasional.republika.co.id/berita/internasional/asia/ptpdzz366/indone sia-tambah-personel-perempuan-pasukan-perdamaian-dunia. [Accessed: 15Dec-2019].

[4] L. F. Hutabarat, "The Development of Indonesian Female Peacekeepers in the United Nations Peacekeeping Mission," J. Def. State Def., pp. 71-90, 2017.

[5] R. P. Hadi and S. Soesilowati, "The role of women in security Indonesian women peacekeepers in the UNIFIL: Challenges and opportunities," Masyarakat, Kebud. dan Polit., vol. 31, no. 4, pp. 380-388, 2018.

[6] F. B. Timur, "The Tales of Three Asian Countries: How Indonesia, India and the Philippines Recruited Women for UN Peacekeeping Missions," Glob. J. Polit. Int., vol. 18, no. 1, pp. 51-75, May 2016.

[7] U. S. Bakry, Metode Penelitian Hubungan Internasional. Yogyakarta: Pustaka Pelajar, 2018.

[8] D. L. Threedy, "Feminist \& Contract Doctrine," pp. 1247-1265, 1999.

[9] K. T. Bartlett, "Feminist Legal Methods," Harv. Law Rev., vol. 103, no. 4, pp. 
829-888, 1990.

[10] Y. S. Alkan, "Feminist legal methods: theoretical assumptions, advantages, and potential problems," Ankara Law Rev., vol. 9, no. 2, pp. 157-174, 2012.

[11] L. A. Clougherty, "Feminist Legal Methods and the First Amendment defese to Sexual Harrasement Liability," Neb. Law Rev., vol. 75, no. 1, pp. 1-26, 1996.

[12] Badan Pusat Statistik, "Statistika Indonesia Statistical Yearbook of Indonesia 2018," 2018.

[13] A. Rahma, "Kapolri: Keluhkan Jumlah Polwan di Indonesia Masih Sedikit," 2018. [Online]. Available: https://nasional.tempo.co/read/1159227/kapolrikeluhkan-jumlah-polwan-di-indonesia-masih-sedikit. [Accessed: 15-Dec2019].

[14] Fitriani, "PRE-DEPLOYMENT TRAINING OF UN WOMEN MILITARY PEACEKEEPERS : A CASE STUDY ANALYSIS OF THREE SOUTHEAST ASIAN COUNTRIES CRANFIELD DEFENCE AND SECURITY PhD THESIS Academic Year 2015-16 Supervisor: Professor Ron Matthews," Cranfield, 2016.

[15] Pemerintah Indonesia, Peraturan Presiden Nomor 85 Tahun 2011. Indonesia, 2011, pp. 1-4.

[16] Pemerintah Indonesia, "Peraturan Menteri Luar Negeri Republik Indonesia Nomor 05 Tahun 2015," pp. 1-29, 2015.

[17] Pemerintah Indonesia, Peraturan Presiden Nomor 86 Tahun 2015. 2015, pp. $1-4$.

[18] Pemerintah Indonesia, "Peraturan Menteri Luar Negeri Republik Indonesia Nomor 1 Tahuhn 2017,” pp. 1-48, 2017. 